\title{
Energy Self-sufficient Farmstead: Design Analysis
}

\author{
D. S. Khatawkar ${ }^{1 *}$, P. S. James ${ }^{2}$ and D. Dhalin ${ }^{3}$ \\ ${ }^{1}$ Department of Farm Machinery and Power Engineering, \\ Kerala Agricultural University, Thrissur - 679 573, India \\ ${ }^{2}$ Agricultural Research Station, Mannuthy, \\ Kerala Agricultural University, Thrissur - 681 651, India \\ ${ }^{3}$ Department of Agricultural Engineering, College of Agriculture, Vellayani - 695 522, India \\ *Corresponding author
}

\section{A B S T R A C T}

In developing countries (Asia and Africa), especially in rural areas, 2.5 billion people rely on biomass, such as fuelwood, charcoal, agricultural wastes and animal dung, to meet their energy needs for cooking and other household use (Kibria, 2015). These resources (biomass) account for over 90\% of household energy consumption. About $77 \%$ and $61 \%$ of population use solid fuels (wood, charcoal) for cooking in Africa and Asia respectively. Use of biomass for energy

Keywords

Energy selfsufficiency, Renewable energy, Farmstead, Biomass

Article Info

Accepted:

22 March 2020

Available Online:

10 April 2020 (to cook meals and other purposes), expose rural people and their families to hazards of smoke and fumes. About 1.3 million people all over globe, mostly women and children, die prematurely every year because of exposure to indoor air pollution from biomass. These threats can only be overcome by producing energy and food in a sustainable way that creates less waste and pollution. Sustainable energy includes renewable energy sources, such as solar energy, wind energy, biogas, hydroelectricity, geothermal energy, bioenergy, tidal power (OECD-IEA, 2006). The concept of energy self-sufficient farmstead incorporates various aspects of renewable energy utilization viz. biomass conversion techniques, solar energy (photovoltaic and thermal), wind power and effective management system for the household effluents and crop residues to meet the entire energy demand throughout the year. In order to reduce environmental pollution and related health hazards, the conventional practices like fuelwood burning for household use and burning crop residues in field need to be replaced by the efficient techniques such as biogas production, biodiesel production, biomass gasification and wood to charcoal conversion (IRENA, 2015).

\section{Introduction}

In developing countries (Asia and Africa), especially in rural areas, 2.5 billion people rely on biomass, such as fuelwood, charcoal, agricultural wastes and animal dung, to meet their energy needs for cooking and other household use (Kibria, 2015). 
In many countries, these resources (biomass) account for over $90 \%$ of household energy consumption. About $77 \%$ and $61 \%$ of population use solid fuels (wood, charcoal) for cooking in Africa and Asia respectively. Use of biomass for energy (to cook meals and other purposes), expose rural people and their families to hazards of smoke and fumes. About 1.3 million people all over globe, mostly women and children, die prematurely every year because of exposure to indoor air pollution from biomass. These threats can only be overcome by producing energy and food in a sustainable way that creates less waste and pollution. Therefore, we need energy sources which are sustainable that will not lead to further increase in the $\mathrm{CO}_{2}$ in the earth's atmosphere. Sustainable energy is the form of energy obtained from inexhaustible resources (renewable resources that can be replenished naturally). Provision of this form of energy serves the needs of the present without compromising the ability of future generations to meet their needs. Sustainable energy includes renewable energy sources, such as solar energy, wind energy, biogas, hydroelectricity, geothermal energy, tidal power (OECD-IEA, 2006).

\section{Energy self-sufficient farmstead}

The concept of energy self-sufficient farmstead incorporates various aspects of renewable energy utilization viz. biomass conversion techniques, solar energy (photovoltaic and thermal), wind power and effective management system for the household effluents and crop residues to meet the entire energy demand throughout the year. In order to reduce environmental pollution and related health hazards, the conventional practices like fuelwood burning for household use and burning crop residues in field need to be replaced by the efficient techniques such as biogas production, biodiesel production, biomass gasification and wood to charcoal conversion. The energy self-sufficiency also brings out socio-economic betterment of individual as well as the community in rural area. The remote areas could be energized in absence of grid power by implementing sustainable renewable energy utilization, which may promote faster social and economic development. With the concept of energy self-sufficiency, one can imagine the clear path for the fundamental facilities such as primary health clinics, educational institutes and transportation.

\section{Strategic points of consideration}

Cultivable land area
Irrigation water availability
Climatic factors and cropping system
Housing for grower's family and other
farm buildings
Renewable energy utilization and
Effective waste management system
Cost economics

\section{Cultivable land area}

Land is to be considered the most important aspect of production, especially agricultural production. Regardless of the advancement of industrial civilization and the subsequent decline of vegetable civilization or agriculture, the problem of food security and the availability of cultivable land still remain crucial. The cultivable land area is declining steadily due to industrial development; hence the problem of providing food sustenance to the rapidly increasing human population is serious.

Productivity is one of the major factors in the perspective of sustainable farming, which refers to agricultural production per unit area cultivated. In order to strengthen the food sustenance, crop productivity has to be enhanced by improving soil fertility, soil manipulation and timely operations. 
In the context of energy self-sufficient farmstead, the gross available land area should include crop field, housing for family, machinery yard, cattle shed, grain and crop residue storage space, vegetable garden, farm pond and space for setting up of various renewable energy harnessing systems etc.

The gross area required could be chosen by knowing total crop production, size of family, number of farm machines and equipment, number of cattle, size of farm pond and area required for installation of renewable energy systems.

\section{Irrigation water availability}

Characteristics of demand for irrigation water relate to quantity, location, timing and quality. Irrigation generally requires large volume of water and usually has to be transported over some distance to the field. For surface water, canals and pipes can enable conveyance; in the case of groundwater, extraction is provided via tube wells or open wells.

In terms of timing, demand for irrigation water can extend through the growing season and, where adequate supplies are available; extend into the dry season for multiple cropping. Peak demand for irrigation water does not usually coincide with peak flows of surface water. This creates the need for storage facility, which naturally occurring water bodies (lakes, wetlands and aquifers) or specially constructed dam or farm pond may provide. Although the quality of water required for irrigation is low, high levels of salinity preclude its use for irrigation, and contaminated supplies can reduce the quality of produce.

However, in case of present topic, if nearby stream or canal or natural reservoirs are not available (or not feasible to avail), fresh water source for both irrigation and household use has to be established within the concerned area. An open well of sufficient diameter can serve the household demand and irrigation supply partially. For an adequate irrigation water supply throughout cultivation period in such situation, rainwater harvesting techniques such as plastic lined dugout farm pond. The farm pond could be designed for the peak water requirement during dry period, depending on cropping pattern, annual rainfall and evaporation losses.

\section{Climatic factors and cropping system}

Crops are dependent on light, temperature, moisture and carbon dioxide $\left(\mathrm{CO}_{2}\right)$ concentration to produce the grains and other crop products that are so essential to our nutrition, health and well-being. However, the levels of these climate inputs, particularly rainfall, vary between locations and years, in part due to climate variability. Temperature and water supply also vary over the longterm, including in response to climate change, with major implications for crop production, and the livelihood of crop producers.

Crop management is therefore about managing climate risk so as to have financially viable and sustainable agricultural systems. Climate and management also impact on the spread of weeds, pests and diseases, which in turn affects crop yield, production cost and net returns.

To maximize the yield and the net income in turn from the limited area, cropping pattern plays an important role. Since, the precise cropping pattern is essential to achieve optimum productivity; it must be given a significant weight of consideration during planning. The cropping pattern is the strategic arrangement and sequencing of the area under different crops based at a point of time and climatic conditions. 


\section{Housing for grower's family and other farm buildings}

Planning is the first and most important step in designing a farmstead. While it costs very little to change a plan on paper, the expense of altering a finished building can be prohibitive, and a poorly conceived arrangement of buildings can diminish profits far into the future. Construction of a new or development of an existing, farmstead generally is a long-term project and needs a good planning. The modern farmstead layout should provide efficiency, security, and safety. The planning process should clearly define the relationship of each structure, or farmstead feature, to the overall goal.

Every farmstead is unique. The various factors must be evaluated and reasonable compromises should be made. An example of such a compromise might be the distance between the home and a large, free-stall dairy barn. Convenience and efficiency might indicate very close proximity. Fire safety might indicate a minimum clearance of $100 \mathrm{ft}$ $(30 \mathrm{~m})$. Freedom from unpleasant odours might suggest several hundred feet. The compromise would be something in between 150 to $200 \mathrm{ft}$ (45 to $60 \mathrm{~m}$ ) (Dhia, 2015).

Orientation on a gentle southern slope may be desirable for air, drainage and maximum sunshine. However, prevailing winds should also be taken into account and natural barriers used where possible.

Any plans for farmstead development should anticipate growth in the enterprise and the layout should facilitate expansion of buildings and services. Increased production volume may require more than existing or larger buildings. It is wise to look for twice as much area as that required initially and, in developing a layout, recognize the full impact of increasing production volume in the future.

\section{Building arrangement}

The arrangement of facilities for maximum efficiency of operation should be the prime concern in farmstead planning. Proper arrangement increases efficiency by reducing walking distances to a minimum and providing adequate driveways and turnarounds. It can also minimize the negative and utilize the positive effects of climatic elements (sun, wind and rain) and will in turn be influenced by drainage, slope, and other topographic features. Finally, fire protection, safety, and security are all influenced by the farmstead layout. When a site has been selected, a large-scale map should be drawn and all major details indicated. These should include contour lines, the direction of north, the direction of prevailing winds and the general slope, existing roads, natural wind barriers and waterways. Using model cut-outs drawn to the same scale as the map, buildings then can be arranged and rearranged until a satisfactory layout is designed. Although not present on many farms, it is generally convenient to consider that a farmstead layout has four basic areas:

\section{A house or/and operation centre}

Machinery yard

Feed and grain storage and primary processing

The livestock areas

\section{Prevailing winds}

Winds can blow from all directions, but the prevailing summer breezes and winter winds need to be considered in farmstead planning. As a general rule, winter winds sweep in from the north or northwest while summer breezes blow from the south, southwest, west, southeast or east. Local conditions may further alter wind patterns, and information on prevailing winds for a given locality should be obtained from the local weather station. 
Winds carry odours, dust, microorganisms, and noise, and prudent arrangement of buildings will use the wind to carry these away from the living centre. Livestock yards and buildings should be located down-wind from the farmhouse and farm neighbours. Several buildings lined up at right angles to the wind rather than parallel are less subject to the spread of fire.

\section{Solar thermal energy}

Proper design allows utilization of solar effects in the winter and minimizes solar heating in the summer. The general rule is to locate the long dimension east-west and allowing maximum solar penetration on the south. Open-front buildings, stockyards, and solar-heated facilities should be arranged so that in winter they receive the full benefit of sunlight throughout the day.

The late afternoon summer sun exposure is minimized by facing the smaller end wall toward the west. The direct radiation of the low angle winter sun on the longer south wall can enter through open walls, doors or windows along a long southern wall. A roof overhang can help to keep out the high angle summer sun.

\section{Distances / Clearances}

Labour efficiency is improved by reducing travel to a minimum. Buildings between which the most travel will occur should be located close together. If separate feed storage structures are used, locate them as close as possible to where the feed will be used. Arrange buildings in relation to drive and yard to allow easy manoeuvring of large vehicles and equipment.

The distance between buildings usually is determined by a compromise involving efficiency, fire safety, odour control, disease control, and available space. Fifty to $100 \mathrm{ft}$
( 15 to $30 \mathrm{~m}$ ) is usually considered a minimum safe distance between buildings or groups of buildings. This minimizes the risk of fire spread and permits access for fighting fire.

The family living area should be protected from noise, odours, dust, and hazards to children. Machinery and supply storages and the farm shop may be located about $100 \mathrm{ft}$ (30 $\mathrm{m})$ from the house, where they are easily accessible and, being relatively quiet and odour free, do not create a nuisance. Sheep and young animals that need supervision, but do not develop heavy odours and waste, can be located within 200 to $300 \mathrm{ft}$ (60 to $90 \mathrm{~m}$ ). Large animal units should be located $300 \mathrm{ft}$ (90 $\mathrm{m})$ or more from the house. This not only reduces the danger of odours reaching the home but also places the unit, which is most likely to be expanded in an area where space will be available.

\section{Renewable energy utilization}

Renewable energy technologies for rural and semi-urban electrification is more sustainable; suitable for supplying geographically dispersed villages by means of distributed energy often without relying on a national grid. Grid connection to remote and dispersed villages is expensive and technically difficult; therefore, individual or local mini-grids developed from renewable energy sources can be established and serve the purpose of rural electrification as stand lone power generating unit. The certain ways to utilize the renewable energy are as given below,

\section{Biomass conversion}

The majority of the rural population relies on traditional biomass to meet their cooking and heating needs. The challenge is to ensure more efficient and sustainable use of biomass for heat extraction, cooking and generation of electricity instead of using raw biomass. 
Conventionally, biomass is harvested for feed, food, fibre, and materials of construction or is left in the growth areas where natural decomposition occurs. The decomposing biomass or the waste products from the harvesting and processing of biomass, if disposed on or in land, can in theory be partially recovered after a long period of time as fossil fuels. Instead of direct heating applications by collection and combustion, the energy content of biomass could be diverted through methods discussed below,

\section{Thermochemical processes}

These processes do not necessarily produce useful energy directly, but under controlled temperature and oxygen conditions are used to convert the original biomass feedstock into more convenient forms of energy carriers, such as producer gas, oils or methanol. These carriers are either more energy dense and therefore reduce transport costs, or have more predictable and convenient combustion characteristics allowing them to be used in internal combustion engines and gas turbines and these are:

Pyrolysis.

Carbonisation.

Gasification.

Catalytic Liquefaction.

\section{Pyrolysis}

Pyrolysis is the application of heat to a feedstock in the absence of oxygen to break down the long chain molecules into short chain molecules. Typically the feedstock is biomass or waste, and the process is used to produce a syngas (a mixture of hydrogen, volatile organic compounds, and carbon monoxide). The advantage of pyrolysis and gasification are that they convert solid material into gases and vapours which are less costly to handle, transport and store. The gases can run boilers, gas turbines and reciprocating engines increasing fuel flexibility and security. Capturing and combusting the methane and carbon monoxide in syngas makes use of the energy in the gas and produces carbon dioxide which is a less potent greenhouse gas than methane and offsets fossil fuel energy production. The shortcomings of pyrolysis and gasification are that they require heat input to drive the chemical reactions that produce a syngas. Thus some fuel must be used to start up the reaction.

\section{Carbonisation}

This is an age old pyrolytic process optimised for the production of charcoal. Traditional methods of charcoal production have centred on the use of earth mounds or covered pits into which the wood is piled. Control of the reaction conditions is often crude and relies heavily on experience. The conversion efficiency using these traditional techniques is believed to be very low; on a weight basis estimates that the wood to charcoal conversion rate for such techniques ranges from 6 to 12 tonnes of wood per tonne of charcoal.

During carbonisation most of the volatile components of the wood are eliminated; this process is also called "dry wood distillation." Carbon accumulates mainly due to a reduction in the levels of hydrogen and oxygen in the wood. The wood undergoes a number of physico-chemical changes as the temperature rises. Between 100 and $170^{\circ} \mathrm{C}$ most of the water is evaporated; between $170^{\circ} \mathrm{C}$ and $270^{\circ} \mathrm{C}$ gases develop containing condensable vapours, $\mathrm{CO}$ and $\mathrm{CO} 2$. These condensable vapours (long chain carbon molecules) form pyrolysis oil, which can then be used for the production of chemicals or as a fuel after cooling and scrubbing. 


\section{Gasification}

Gasification is the partial oxidation of an organic feedstock to produce a syngas or producer gas (a mixture of hydrogen, methane and carbon monoxide). Typically the feedstock is biomass or waste, and varying the process conditions allows control over proportions of the compounds in the syngas. In this approach to the development of fixed carbon supplies from renewable carbon resources is to convert $\mathrm{CO}_{2}$ outside the biomass species to synthetic fuels and organic intermediates. The ambient air, which contains about $360 \mathrm{ppm}$ by volume of $\mathrm{CO}_{2}$, the dissolved $\mathrm{CO}_{2}$ and carbonates in the oceans, and the earth's large carbonate deposits, could serve as renewable carbon resources. Since, $\mathrm{CO}_{2}$ is the final oxidation state of fixed carbon, it contains no chemical energy. Energy must be supplied in a chemical reduction step. A convenient method of supplying the required energy and of simultaneously reducing the oxidation state is to reduce $\mathrm{CO}_{2}$ with hydrogen. The end product, for example, can be methane $\left(\mathrm{CH}_{4}\right)$, the dominant component in natural gas and the simplest hydrocarbon known (Ajaykumar et al., 2009).

The chemical reactions involved in the process of gasification are as follows,

$\mathrm{CH}_{\mathrm{x}} \mathrm{O}_{\mathrm{y}}$ (biomass) $+\mathrm{O}_{2}$ (21\% of air) $+\mathrm{H}_{2} \mathrm{O}$ (steam)

$=\mathrm{CH}_{4}+\mathrm{CO}+\mathrm{CO}_{2}+\mathrm{H}_{2}+\mathrm{H}_{2} \mathrm{O}$ (unreacted steam $)+\mathrm{C}($ char $)+$ tar

$2 \mathrm{C}+\mathrm{O}_{2}=2 \mathrm{CO}$ (partial oxidation reaction)

$\mathrm{C}+\mathrm{O}_{2}=\mathrm{CO}_{2}$ (complete oxidation reaction) ...(3)

$\mathrm{C}+2 \mathrm{H}_{2}=\mathrm{CH}_{4}$ (hydrogasification reaction) ...(4)
$\mathrm{CO}+\mathrm{H}_{2} \mathrm{O}=\mathrm{CO}_{2}+\mathrm{H}_{2}$ (water gas shift reaction) ...(5)

$\mathrm{CH}_{4}+\mathrm{H}_{2} \mathrm{O}=\mathrm{CO}+3 \mathrm{H}_{2}$ (steam reforming reaction)

$\mathrm{C}+\mathrm{H}_{2} \mathrm{O}=\mathrm{CO}+\mathrm{H}_{2}$ (water gas reaction) ...(7)

$\mathrm{C}+\mathrm{CO}_{2}=2 \mathrm{CO}$ (Boudourd reaction) $\ldots(8)$

High temperatures and a controlled environment lead to virtually major portion of the raw material being converted to gas. This takes place in two stages. In the first stage, the biomass is partially combusted to form producer gas and charcoal. In the second stage, the $\mathrm{CO}_{2}$ and $\mathrm{H}_{2} \mathrm{O}$ produced in the first stage are chemically reduced by the charcoal, forming $\mathrm{CO}$ and $\mathrm{H}_{2}$. The composition of the gas is 18 to 20 per cent of $\mathrm{H}_{2}$, an equal portion of $\mathrm{CO}, 2$ to 3 per cent of $\mathrm{CH}_{4}, 8$ to 10 per cent of $\mathrm{CO}_{2}$, and the rest nitrogen (Rahman et al., 2013).

\section{Catalytic Liquefaction}

This technology has the potential to produce higher quality products of greater energy density. These products should also require less processing to produce marketable products. Catalytic liquefaction is a low temperature, high pressure thermochemical conversion process carried out in the liquid phase. It requires either a catalyst or a high hydrogen partial pressure. Technical problems have so far limited the opportunities of this technology.

\section{Biochemical processes}

The use of micro-organisms for the production of ethanol is an ancient art. However, in recent times such organisms have become regarded as "biochemical factories" for the treatment and conversion of most forms of human generated organic 
waste. Microbial engineering has encouraged the use of fermentation technologies (aerobic and anaerobic) for use in the production of energy (biogas) and fertilizer (Wazed, 2010). The major biochemical methods for biomass conversion are,

Anaerobic Digestion

Ethanol Fermentation

\section{Anaerobic digestion}

Anaerobic digestion is the microbial digestion of feedstock releasing heat, methane, hydrogen sulphide, carbon dioxide and under specific conditions hydrogen gas. This process takes place over several days in digester tanks where the ideal conditions are maintained. After the process the remaining solid digestate is suitable for use as fertiliser and the gases released are collectively referred to as biogas. Anaerobic reactors are generally used for the production of methane rich biogas from manure (human and animal) and crop residues. They utilise mixed methanogenic bacterial cultures which are characterised by defined optimal temperature ranges for growth. These mixed cultures allow digesters to be operated over a wide temperature range i.e. above $0^{\circ} \mathrm{C}$ up to $60^{\circ} \mathrm{C}$.

The chemical reaction involved is,

$\mathrm{C}_{6} \mathrm{H}_{12} \mathrm{O}_{6} \rightarrow 3 \mathrm{CO}_{2}+3 \mathrm{CH}_{4}$

When functioning well, the bacteria convert about $90 \%$ of the feedstock energy content into biogas (containing about 55\% methane), which is a readily useable energy source for cooking and lighting. The sludge produced after the manure has passed through the digester is non-toxic and odourless. Also, it has lost relatively little of its nitrogen or other nutrients during the digestion process thus, making a good fertiliser. In fact, compared to cattle manure left to dry in the field the digester sludge has higher nitrogen content; many of the nitrogen compounds in fresh manure become volatised whilst drying in the sun. The advantage of anaerobic digestion is that it naturally occurs to organic material and would release methane, a potent greenhouse gas, into the atmosphere. Capturing and combusting the methane makes use of the energy in the gas and produces carbon dioxide which is a less potent greenhouse gas than methane and also offsets fossil fuel energy production.

\section{Ethanol Fermentation}

Ethanol is mainly used as a substitute for imported fuel oil in order to reduce their dependence on imported energy supplies. The substantial gains made in fermentation technologies now make the production of ethanol for use as a petroleum substitute and fuel enhancer, both economically competitive and environmentally beneficial. The most commonly used feedstock in developing countries is sugarcane, due to its high productivity when supplied with sufficient water. Where water availability is limited, sweet sorghum or cassava may become the preferred feedstocks. Other advantages of sugarcane feedstock include the high residue energy potential and modern management practices which make sustainable and environmentally benign production possible while at the same time allowing continued production of sugar. Other preferable feedstocks include saccharide-rich sugarbeet, and carbohydrate rich potatoes, wheat and maize. The after glycolysis, the glucose molecule is decomposed by the yeast to form ethanol and carbon dioxide as given below,

$$
\mathrm{C}_{6} \mathrm{H}_{12} \mathrm{O}_{6}+\text { yeast } \rightarrow 2 \mathrm{C}_{2} \mathrm{H}_{5} \mathrm{OH}+2 \mathrm{CO}_{2}
$$

\section{Solar energy}

Solar energy can be utilized in a planned direct or indirect way. In the case of indirect utilization of solar energy we consider the use 
of renewable energies which are secondary effects of solar energy (Kibria et al., 2013) i.e., wind energy, hydro energy, ocean energy, and secondary energy from photosynthetic process that is mostly connected with the use of biomass and biofuels as discussed before. Using solar energy in the direct way we can apply two fundamental methods of energy conversion:

a) Photothermal conversion of energy of solar radiation;

b) Photoelectric conversion of energy of solar radiation.

Applying a photothermal conversion of solar radiation energy we consider usually the following systems:

- Active low temperature solar water and air heating or cooling systems, which includes;

- solar water heating systems with flat plate or vacuum solar collectors,

- solar air heaters, including crop driers,

- solar space cooling systems coupled with sorption refrigerator,

- solar ponds, which are solar collectors and heat stores at the same time. They comprise several layers of salty water. With the increase of depth the salinity (density) increases, convection is suppressed, and the bottom layer is the hottest,
- solar stills for distilling water.

- Passive low temperature solar heating or cooling systems, which constitute solar architecture;

- High temperature solar systems with solar concentrators, in which a working fluid can drive a conventional heat engine to produce mechanical work and if necessary, electricity.

By virtue of photoelectric effect, the solar radiation can cause photovoltaic generation of a power by separating positive and negative charge carriers in the absorbing material. In a presence of an electric field, the charge carriers can produce a current. Photoelectric devices are electrical current sources driven by a flux of incident solar radiation.

\section{Cost economics}

\section{Solar PV system}

A solar PV system design can be done in four steps:

Load estimation

Estimation of number of PV panels

Estimation of battery bank

Cost estimation of the system.

Table.1 Calculation of daily electricity consumption for a farmstead

\begin{tabular}{|l|l|c|c|c|c|}
\hline $\begin{array}{l}\text { Sl. } \\
\text { No. }\end{array}$ & Appliance & No./Nos. & $\begin{array}{c}\text { Rated power } \\
(\mathbf{W})\end{array}$ & $\begin{array}{c}\text { Daily usage } \\
(\mathbf{h})\end{array}$ & $\begin{array}{c}\text { Electricity } \\
\text { Consumption (kW-h) }\end{array}$ \\
\hline $\mathbf{1 .}$ & Lighting & 20 & 20 & 8 & 3.2 \\
\hline $\mathbf{2 .}$ & Fans & 4 & 75 & 10 & 3.0 \\
\hline $\mathbf{3 .}$ & Mixer-Blender & 1 & 300 & 0.5 & 0.15 \\
\hline $\mathbf{4 .}$ & Washing Machine & 1 & 500 & 0.5 & 0.25 \\
\hline $\mathbf{5 .}$ & Television & 1 & 150 & 4 & 0.6 \\
\hline $\mathbf{6 .}$ & Iron & 1 & 1000 & 0.5 & 0.5 \\
\hline $\mathbf{7 .}$ & Water pump & 1 & 3728 & 2 & 7.45 \\
\hline $\mathbf{8 .}$ & Refrigerator & 1 & 1000 & 2 & 2.0 \\
\hline & & & & Total & $\mathbf{1 7 . 1 5}$ \\
\hline
\end{tabular}




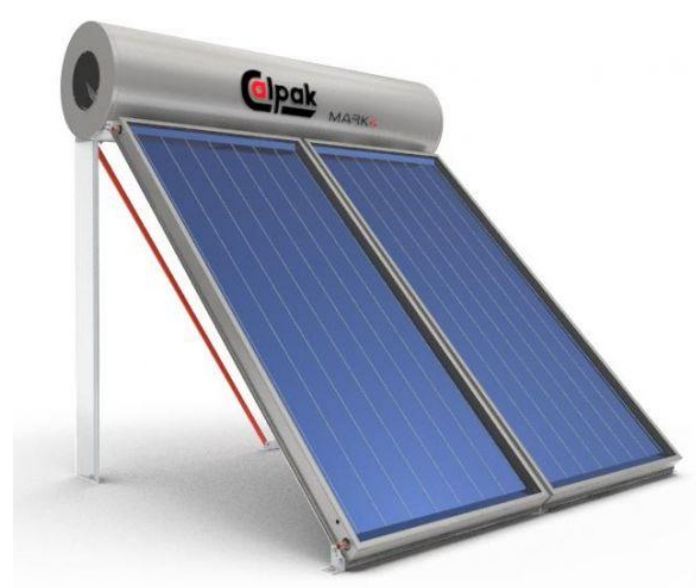

Fig.1 Flat plate solar water heater

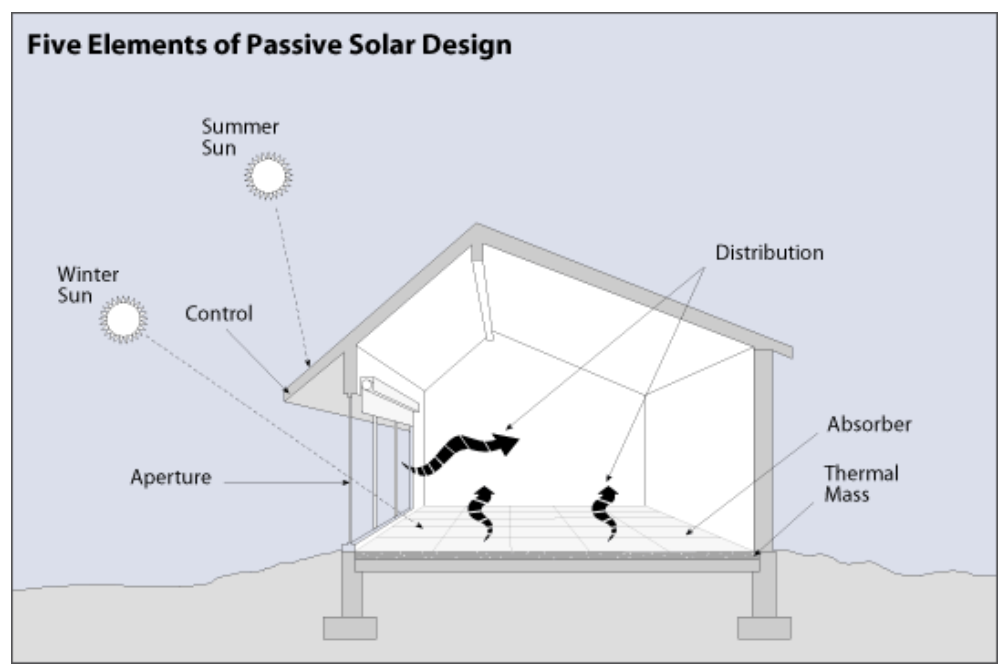

Fig.2 Solar passive space heating

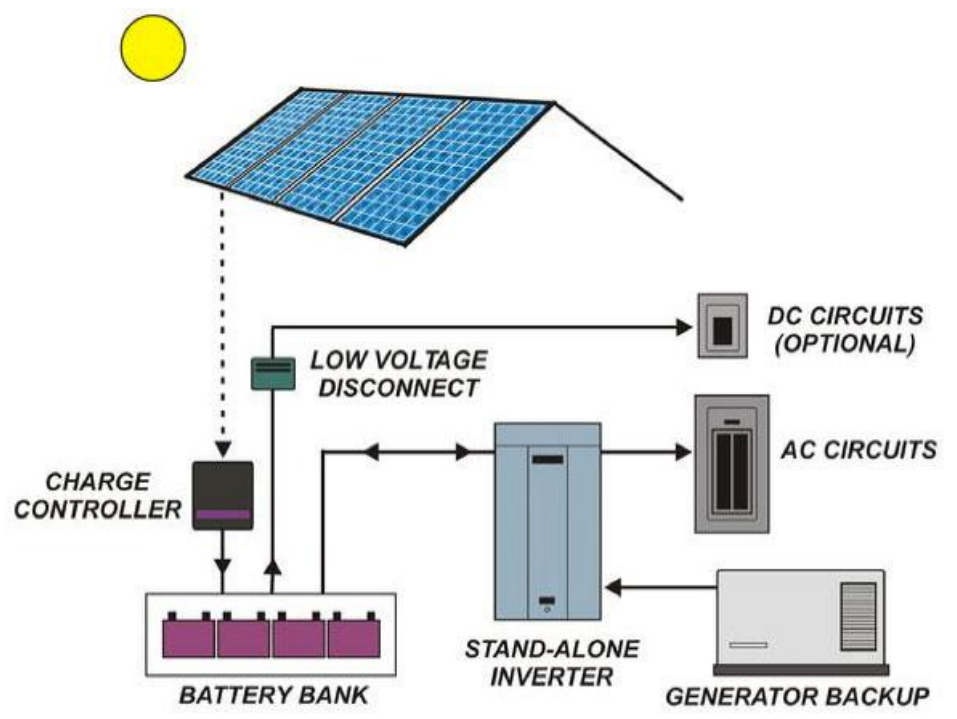

Fig.3 Solar PV system schematics 


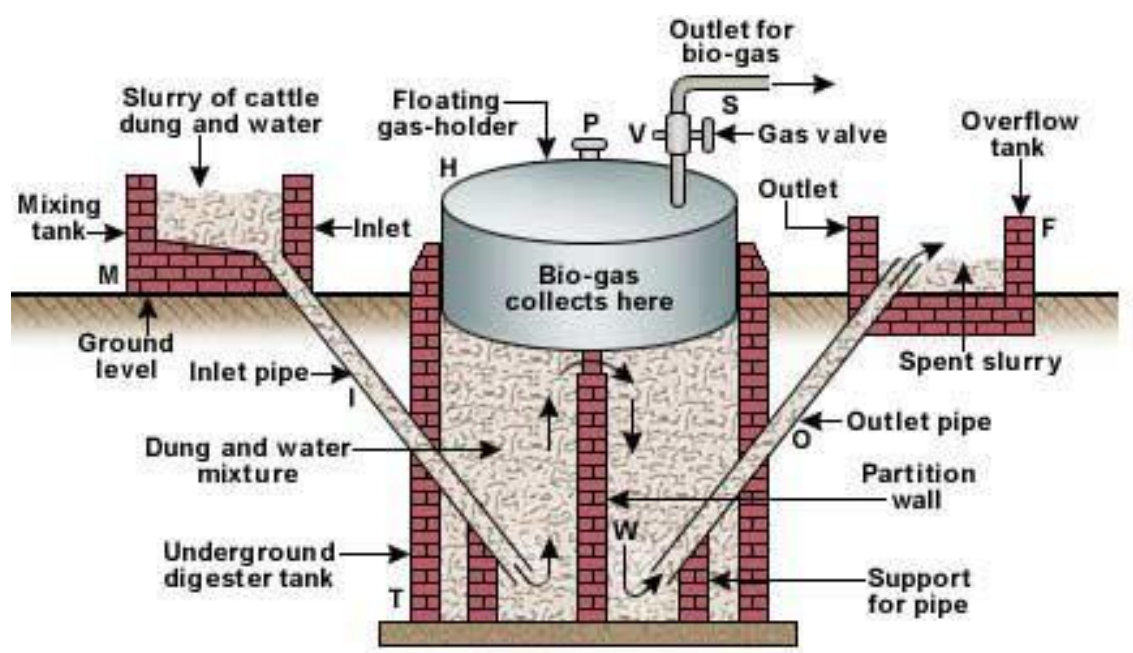

Floating gas-holder type bio-gas plant.

Fig.4 Floating gas holder type biogas plant

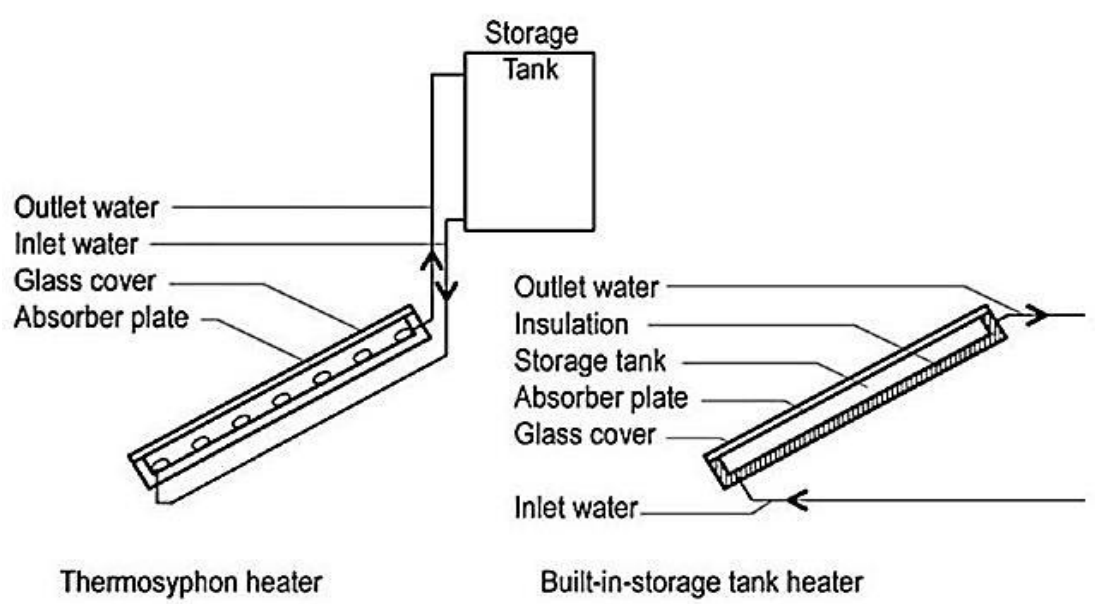

Fig.5 Construction details of solar flat plate water heater

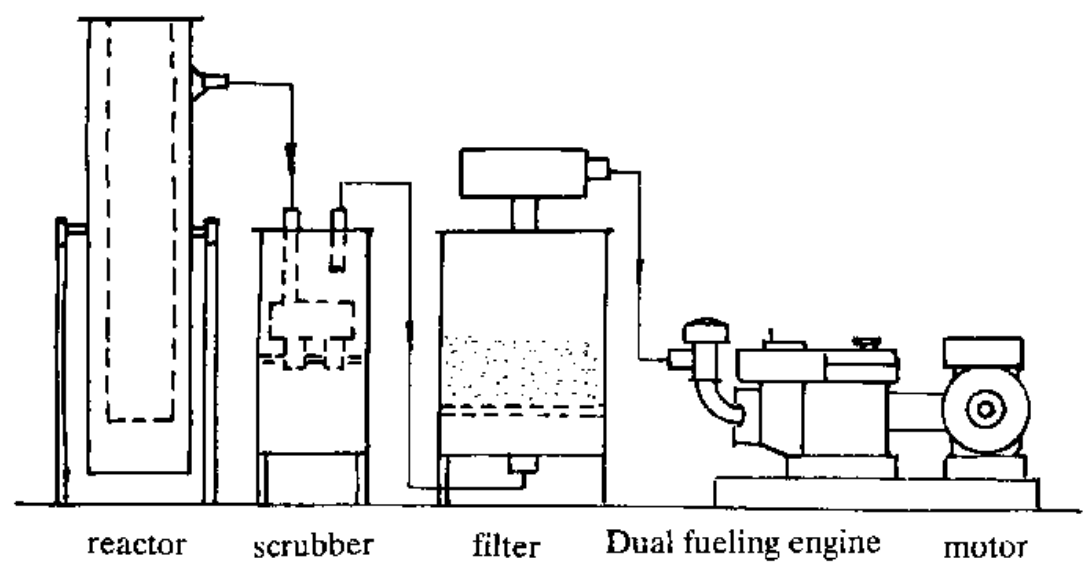

Fig.6 Schematic arrangement of gasifier powered diesel engine generator set 

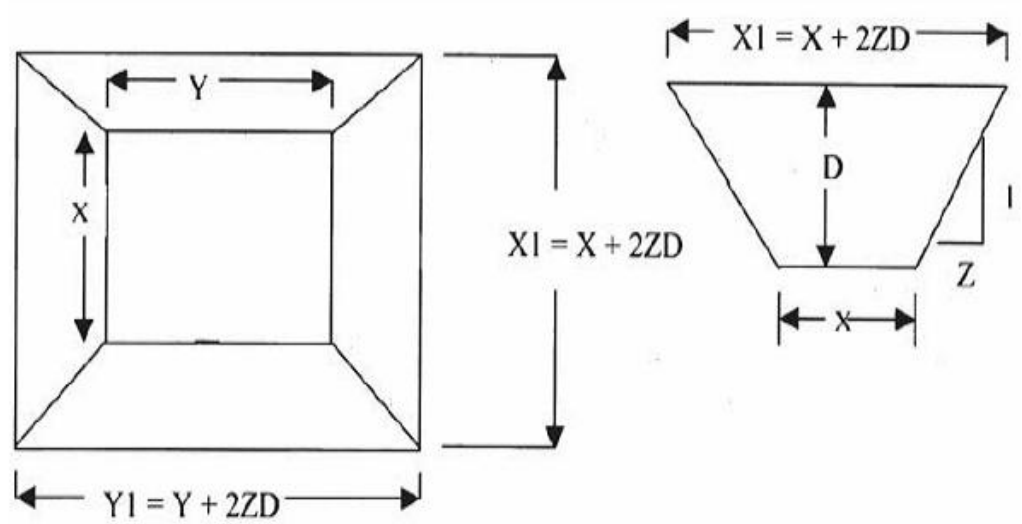

Fig.7 Farm pond design

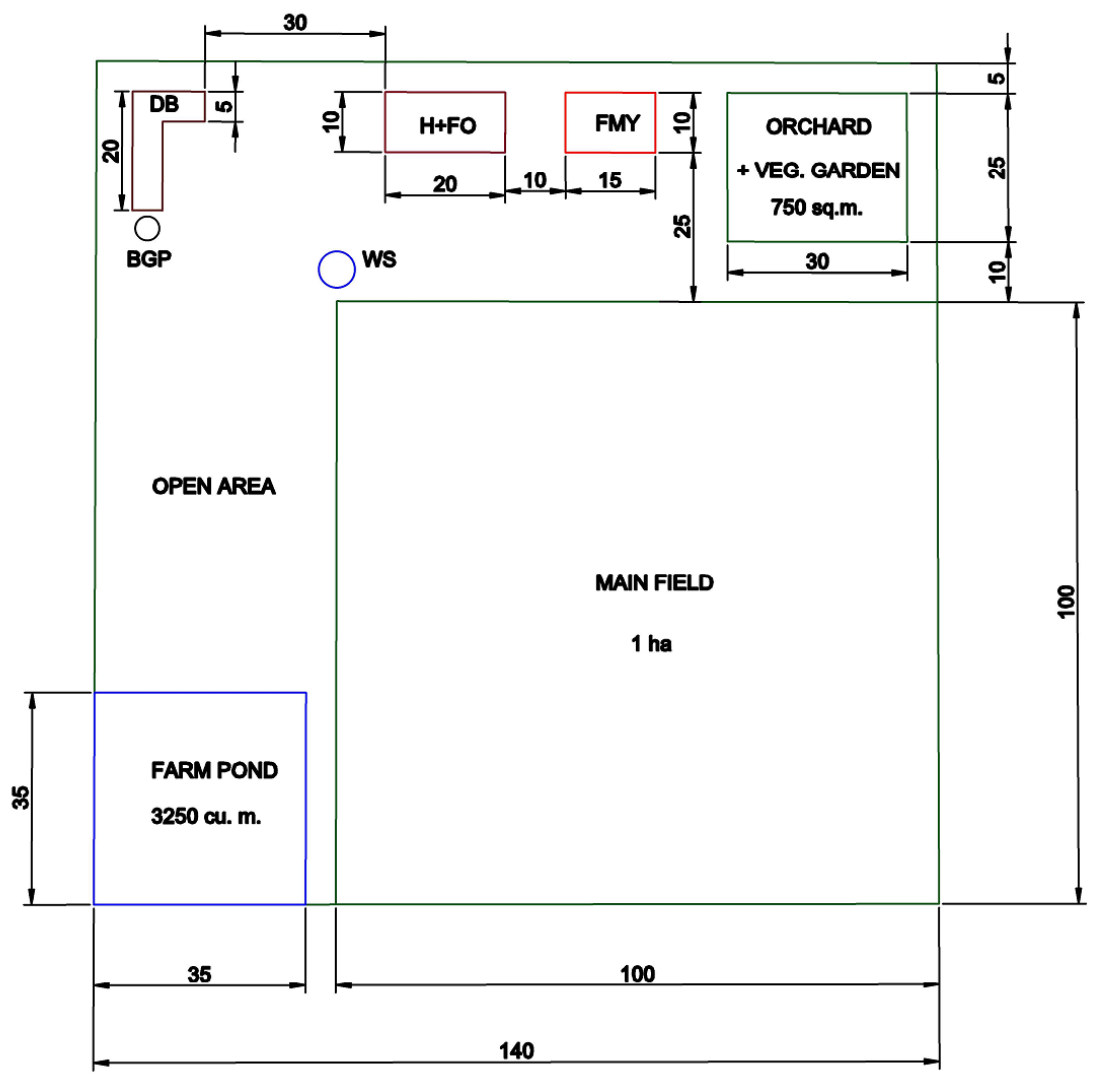

\begin{tabular}{|l|l|}
\hline H+FO & HOMESTEAD + FARM OFFICE \\
\hline FMY & FARM MACHINERY YARD \\
\hline DB & DAIRY BARN \\
\hline BGP & BIOGAS PLANT \\
\hline WS & WATER SOURCE \\
\hline
\end{tabular}

Fig.8 Plan of designed farmstead (all dimensions are in metre)

a) The total energy requirement of the system (total load) i.e. Total connected load to PV panel system $=7.38 \mathrm{~kW}$.

b) Total watt-hours rating of the system 
$=17.15 \mathrm{~kW}-\mathrm{h}$

c) Actual power output of a $40 \mathrm{~W}$ PV panel $=$ Peak power rating $\times$ operating factor

$$
=40 \times 0.75=30 \text { watt }
$$

d) Energy produced by one $40 \mathrm{Wp}$ panel in a day

$=$ Actual power output $\times 8$ hours/day (peak equivalent)

$=30 \times 8=240$ watts-hour

e) Number of solar panels required to satisfy given estimated daily load :

$=($ Total watt-hour rating per day $) /($ Daily energy produced by a panel)

$=17150 / 240=71.45=72$ Nos. (round figure)

f) Inverter size must be selected slightly higher than that of solar panel daily output. Therefore, the choice of the inverter should be $20 \mathrm{kVA}$.

g) Dimensions of a $40 \mathrm{~W}$ PV panel $(\mathrm{HxWxD})=610 \times 655 \times 34 \mathrm{~mm}$

h) Rooftop area required for installation of $72 \mathrm{PV}$ panels

$\mathrm{A}=0.61 \times 0.655 \times 72=28.76 \mathrm{~m}^{2}$

i) Cost of arrays $=$ No. of PV panels $\times$ Cost/panel

$=72 \times 2200=$ Rs. 158400

j) No. of batteries required $=$ Total amphours required per day / (Voltage rating $\mathrm{x}$ amp-hour per battery)

$\mathrm{N}=\frac{30 \times 8}{200}=7.2 \cong 8$ Nos.

k) Cost of batteries $=$ No. of Batteries $\times$ Cost/battery

$=8 \times 15000=$ Rs. 120,000

1) Cost of Inverter $=$ No. of inverters $\times$ Cost $/$ Inverter $=1 \times 10000=$ Rs. 100000

m) Total cost of system $=\mathrm{A}+\mathrm{B}+\mathrm{C}=$ $158000+120000+100000=$ Rs. 378000

n) Savings per month $=\mathrm{kW}$-h per month $x$ cost per unit electricity

$=515 \times 7=$ Rs. 3605

o) Per annum savings $=3605 \times 12=$ Rs. 43260 p) Simple payback period =
$378000 / 43260=8.73$ years

Biogas plant

a) Number of family members $=6$ (adult). Considering 400 litre/day/person for cooking, total gas required $=6 \times 400=2400$ litres/day or about $2.4 \mathrm{~m}^{3}$ gas/day.

b) Amount of gas produced from $1 \mathrm{~kg}$ of fresh dung $=37$ litre $/ \mathrm{kg}$.

c) Total amount of dung required $=$ Total gas required/Gas per $\mathrm{kg}$ of dung

$=2400 / 37=64.86 \mathrm{~kg} \approx 65 \mathrm{~kg}$

Thus, in order to have $65 \mathrm{~kg}$ of dung no. of cows required $=65 / 10=6.5 \approx 7$ cows

\section{Design of digester and gas holder}

In order to make slurry, water should be added to equal amount of dung.

a) Total mass of slurry $=$ Dung+ Water $=$ $65+65=130 \mathrm{~kg}$.

b) Volume of slurry per day (specific gravity of slurry is about $1090 \mathrm{~kg} / \mathrm{m}^{3}$ )

slurry/Specific gravity $=$ Total mass of

$$
=130 / 1090=0.1192 \mathrm{~m}^{3}
$$

c) Retention period of slurry $=50$ days. Total volume of the digester $=$ per day volume of slurry $\times$ retention period $=$ $0.1192 \times 50=5.96 \mathrm{~m} 3 \approx 6 \mathrm{~m}^{3}$

d) Dimensions of the digester : Depth to diameter ratio should be between 1 and 1.3

Volume $={ }^{2} \mathrm{H}=6 \mathrm{~m}^{3}$

e) Assuming height of the digester $(\mathrm{H})=2 \mathrm{~m}$

$D=\sqrt{\frac{6 \times 4}{\pi \times 2}}=1.95 \mathrm{~m}$

Hence, diameter of the digester $(D)=1.95 \approx 2$ $\mathrm{m}$

f) Gas holder dimensions : The volume of 
the gas holder tank should be about $60 \%$ of the per day gas volume.

$60 \%$ of per gas volume $=2.4 \times 0.6=1.44 \mathrm{~m}^{3}$

g) Diameter $\left(\mathrm{D}_{\mathrm{h}}\right)$ of gas holder $=\mathrm{D}-(5 \mathrm{~mm}$ $\times 2$ ) diametral clearance

$$
=2000-10=1990
$$

$=1.99 \mathrm{~m}$

h) Height $\left(\mathrm{H}_{\mathrm{h}}\right)$ of the gas holder = $\frac{\mathrm{k} 4}{\frac{2}{2}}=0.46 \mathrm{~m}$

Various possible costs incurred in manufacturing of a biogas plant are given below:

\section{Component}

1. Gas holder and frame

2. Piping and stove Capital cost (Rs.) 10000 2500

3. Civil engineering construction 25000

The approximate total cost of biogas plant is Rs. 37500

\section{Saving due to use of biogas plant}

Assuming that biogas is replacing the use of LPG in a household, following calculations can be done to calculate the amount savings.

a) The amount of LPG required is about $2 \mathrm{~kg} /$ per person/month

b) Total LPG required for 6 people for a month is $6 \times 2=12 \mathrm{~kg} / \mathrm{month}$

c) Cost of LPG per kg is about Rs. 50

d) Total cost of LPG (if used in place of biogas $)=12 \times 50=$ Rs. 600 per month (this amount is monthly saving.)

e) Total yearly savings $=600 \times 12=$ Rs. 7200 per year

f) Therefore, the simple payback period is $=$ Total cost of biogas plant/yearly savings

$37500 / 7200=5.2$ years

\section{Flat plate solar water heater}

On an average household hot water requirement per person per day is around 15 litres. For a family of 6 members will require 90 litres of hot water per day. The collector area $\left(A_{c}\right)$ for a solar flat plate water heater to supply 100 litres of hot water per day at a temperature of $70^{\circ} \mathrm{C}\left(\mathrm{T}_{\mathrm{h}}\right)$ can be calculated as below,

a) Assuming the average solar radiation intensity available $\left(\mathrm{I}_{\mathrm{st}}\right)=5 \mathrm{kWh}-\mathrm{m}^{-2}$

b) The ambient temperature of water $\left(\mathrm{T}_{\mathrm{i}}\right)$ $=25^{\circ} \mathrm{C}$

c) Collection efficiency $(\mathrm{y})=30 \%$

d) Average sunshine $=8 \mathrm{~h}$ per day

(Source: Mahtta et al., 2014)

We know that,

$\Delta \mathrm{T}=\mathrm{T}_{\mathrm{h}}-\mathrm{T}_{\mathrm{i}}=70-25=45^{\circ} \mathrm{C}$

$m=100 \times 10^{-3} \times 1000=100 \mathrm{~kg}$

$\mathrm{Q}_{\text {in }}=\mathrm{\eta} \times \mathrm{I}_{\mathrm{st}} \times \mathrm{A}_{\mathrm{c}}=\frac{0.3 \times 5 \times 10^{\mathrm{g}} \times A_{c}}{24} ; \mathrm{W}$

$\mathrm{Q}_{\text {use }}=\mathrm{s} \times m \times \Delta \mathrm{T}=\frac{\frac{4200 \times 100 \times 45}{24 \times 3600}}{\mathrm{~A}}=218.75 \mathrm{~W}$

According to calorimetry principle,

$\mathrm{Q}_{\text {in }}=\mathrm{Q}_{\text {use }}$

Therefore,

$\mathrm{A}_{\mathrm{c}}=\frac{24 \times 218.75}{1500}=3.5 \mathrm{~m}^{2}$

But the actual collector area $\mathrm{A}_{\mathrm{c}}=\frac{24}{8} \times 3.5=$ $10.5 \mathrm{~m}^{2}$

Energy required to heat up the amount of water in terms of "kWh"

$\mathrm{P}_{\mathrm{T}}=\frac{4.2 \times \mathrm{W} \times \Delta \mathrm{T}}{3600}=\frac{4.2 \times 100 \times 45}{3600}=5.25 \mathrm{kWh}$

Where,

$\mathrm{P}_{\mathrm{T}}=$ Energy required to heat up the water, $\mathrm{kWh}$

$\mathrm{W}=$ Weight of water, $\mathrm{kg}$

$\Delta \mathrm{T}=$ Temperature difference $\left(\mathrm{T}_{\mathrm{h}}-\mathrm{T}_{\mathrm{i}}\right),{ }^{\circ} \mathrm{K}$

e) The cost of $100 \mathrm{lpd}$ flat plate solar water heater system is around Rs. 30000 
f) The cost water heating using grid power supply @Rs.7 per unit (kWh) is given by,

g) Annual saving on cost of heating = $5 \times 30 \times 12 \times 7=$ Rs. 13230

h) $\begin{aligned} & \text { Simple payback } \\ & \text { ost of installation }\end{aligned}=\frac{30000}{13230}=2.26$ years
Annual saving

\section{Gasifier unit}

The farmer with abundant amount of maize stalks can employ a small scale gasifier unit to operate upto $5 \mathrm{~kW}$ diesel engine generator set for 6 hours a day.

1. Let us assume,

2. Bulk density of biomass $(\rho)=50 \mathrm{~kg}$ $\mathrm{m}^{-3}$

3. Heat value of biomass $\left(\mathrm{H}_{\mathrm{w}}\right)=16 \mathrm{MJ}-$ $\mathrm{kg}^{-1}$

4. Lower calorific value of producer gas $\left(\mathrm{H}_{\mathrm{g}}\right)=5.5 \mathrm{MJ}-\mathrm{m}^{-3}$

5. Overall efficiency $\left(\mathrm{y}_{\mathrm{oa}}\right)=15 \%$

6. Gasification efficiency $\left(\mathrm{y}_{\mathrm{g}}\right)=65 \%$

7. Operation time $(\mathrm{t})=6 \mathrm{~h}$

Calculations can be made as follows,

added.

Therefore,

Total reactor volume $=0.9+0.09=0.99 \mathrm{~m}^{3} \approx$ $1 \mathrm{~m}^{3}$

Area required (A)

$\mathrm{A}=\frac{\mathrm{q}}{\mathrm{SGR}}=\frac{7.5}{75}=0.1 \mathrm{~m}^{2}$

Where, Specific Gasification Rate (SGR) is assumed to be $75 \mathrm{~kg}-\mathrm{h}^{-1} \mathrm{~m}^{-2}$

Therefore, Diameter of reactor (d) is given by,

$\mathrm{d}=\sqrt{\frac{4 \mathrm{~A}}{\pi}}=\sqrt{\frac{4 \times 0.1}{3.14}}=0.201 \mathrm{~m}$

Height of reactor (h) can be found as,

$\mathrm{h}=\frac{\mathrm{V}}{\mathrm{A}}=\frac{0.198}{0.1}=1.98 \mathrm{~m}$

\section{Cost of construction}

Considering MS sheet of $2.5 \mathrm{~mm}$ thickness for fabricating reactor chamber, outer jacket and other minor components with respective materials, the overall cost of construction for the gasifier unit of above dimensions may come around Rs. 10000 to 12000.

\section{Annual savings}

$\mathrm{q}=\frac{3600 \times \mathrm{P}}{\mathrm{\eta}_{\mathrm{og}} \times \mathrm{H}_{\mathrm{w}}}=\frac{3600 \times 5}{0.15 \times 16 \times 1000}=7.5 \mathrm{~kg}-\mathrm{h}_{\text {output, the average fuel consumption is about }}^{\text {Eør a diesel generater set } 5 \mathrm{~kW} \text { power }}$ 1 litre per hour. For ensuring the proper ignition 10-15\% diesel is co-fired during the operation while working producer gas as a major fuel. The amount of co-fired diesel contributes the operational cost of the $\mathrm{Q}=\frac{\mathrm{n}_{\mathrm{g}} \times \mathrm{q} \times \mathrm{H}_{\mathrm{w}}}{\mathrm{H}_{\mathrm{g}}}=\frac{0.65 \times 7.5 \times 16 \times 1000}{5.5 \times 1000}=$

Volume of reactor $(\mathrm{V})$

$\mathrm{V}=\frac{\mathrm{t} \times \mathrm{q}}{\rho}=\frac{6 \times 7.5}{50}=0.9 \mathrm{~m}^{3}$

For safety assurance, $10 \%$ extra volume is generater set,-which may fall between Rs. 10 to 12 per hour. Considering the major operational period (6 hours per day) during three months of rainy season, the total cost of diesel fuel incurred per annum (C) can be calculated as,

$\mathrm{C}_{\mathrm{G}}=$ Fuel cost per hour $X$ Operational period in hours $=12 \times 6 \times 30 \times 3=\mathrm{Rs}, 6480$ 
$5 \mathrm{~kW}$ diesel generator costs around Rs. 1.2 lac

Annual savings on electricity $=$ Daily electric load $\times$ Unit charge $\times$ Operational period

$$
\begin{aligned}
& =17.15 \times 7 \times 30 \times 3 \\
& =\text { Rs. } 10504.5
\end{aligned}
$$

Simple payback period $=$

$\frac{\text { Cost }}{\text { Annual savings }}=\frac{120000+12000}{10504.5}=12.5$ years

\section{Rice cultivation (Rainfed)}

In India, average productivity of rice cultivation is about 2 tons per hectare and in Palakkad (Kerala) region it is about $2557 \mathrm{~kg}$ per hectare. The average straw to grain ratio of paddy ranges between 1:1 to $1: 1.3$ (TNAU Agritech, 2015). Considering an area of one hectare under paddy cultivation with an average yield of 2.5 tons per hectare following calculations could be done,

a) Value of paddy $=$ Yield $(\mathrm{kg}) \times$ MSP $($ Rs. per $\mathrm{kg})=2500 \times 15.50=$ Rs. 38750

b) Minimum Support Price (MSP) of paddy for crop year 2017-18 is Rs. 15.50 per kg (DAC\&FW, 2018a).

c) Straw value @ Rs. 2 per $\mathrm{kg}=2 \times$ $2500=5000$

d) Gross income $=$ Paddy value + Straw value $=38750+5000=$ Rs. 43750 ha $^{-}$

e) Net income $=$ Gross income - Cost of cultivation $=43750-25000=18750$ ha $^{-1}$

f) Benefit-Cost Ratio =

$$
\frac{\text { oss income }}{\text { of cultivation }}=\frac{38750}{25000}=1.55
$$

\section{Maize cultivation}

Maize (Zea mays) is a tall, deep-rooted, warm weather annual grass. Most varieties (Vijay,
Vikram etc.) of corn require 100 to 140 days from seeding to full ripeness of the kernels though some hybrid varieties (Ganga 01, Ganga 101 etc.) will ripen in 80 days. As a rainfed crop, maize is grown in June-July or August-September. The irrigated crop is raised in January-February (Kissan Kerala, n.d.). The straw to grain ratio varies between 1.1:1 to $1.8: 1$ over different varieties (TNAU Agritech, 2015).

a) Irrigated Crop: 5- 6 tons-ha ${ }^{-1}$ (Hybrids) 4.5-5 tons-ha ${ }^{-1}$ (Composites)

b) Rainfed Crop: 2-2.5 tons-ha ${ }^{-1}$ (Hybrids) 1.5-2 tons-ha ${ }^{-1}$ (Composites)

MSP of maize for crop year 2017-18 is Rs. 14.25 per $\mathrm{kg}$ (DAC\&FW, 2018a). Considering the irrigated maize cultivation from January-February to May-June with the average yield of 5 tons-ha ${ }^{-1}$, following cost analysis could be done,

a) Value of grains $=$ Yield $\times$ MSP $=5 \times$ $1000 \times 14.25=$ Rs. 71250

b) Straw value @ Rs. 2 per kg $=2 \times 1.1$ $\times 5000=$ Rs. 11000

c) Gross income $=$ Grain value + Straw value $=71250+11000=$ Rs. 82250 $\mathrm{ha}^{-1}$

d) Net income $=$ Gross income - Cost of cultivation $=82250-45000=$ Rs. 37250 ha $^{-1}$

e) Benefit-Cost Ratio = $\frac{\text { oss income }}{\text { of cultivation }}=\frac{82250}{45000}=1.83$

\section{Green gram cultivation}

Green gram is grown as a pure crop in rice fallows after the harvest of the first or second crop of paddy. It can also be grown as a mixed crop with tapioca, colocasia, yam, and banana or as an intercrop in coconut gardens.

Varieties: Philippines, Madiera, Pusa Baisakhi, NP-24, Co-2, Pusa-8973 (Pusa- 
8973 is suited to the summer rice fallows of Onattukara; tolerant to pod borer; duration 66 days).

Seed rate: $20-25 \mathrm{~kg} \mathrm{ha}^{-1}$

Sowing: Plough the land 2-3 times thoroughly and remove weeds and stubbles. Channels, 30 $\mathrm{cm}$ broad and $15 \mathrm{~cm}$ deep, are drawn at $2 \mathrm{~m}$ apart to drain off excess rain water during kharif season and provide irrigation during summer season. The seeds may be sown broadcast.

Yield : 8 to 10 quintals-ha ${ }^{-1}$

MSP for Green gram : Rs. 5375 per quintal (DAC\&FW, 2018a).

Average cost of cultivation : Rs. 25000 ha $^{-1}$

Value of produce $=$ Yield (quintals-ha ${ }^{-1}$ ) $\times \operatorname{MSP}($ Rs. per quintal $)=8 \times 5375=$ Rs. 43000

Gross income $=$ Grain value $=$ Rs. 43000 ha $^{-1}$

Net income $=$ Gross income - Cost of cultivation $=43000-25000=$ Rs. 18000 ha $^{-1}$

Benefit-Cost Ratio =

$\frac{\text { soss income }}{\text { of cultivation }}=\frac{43000}{25000}=1.72$

\section{Milk production}

Considering 7 cattle ( 2 bullocks and 5 cows) dairy barn, with average milk yield per cow per day of 6 litres the following cost analysis could be done,

Milking per day $=$ No. of cows $\times$ Yield per cow $=5 \times 6=30$ litres

Out of household daily milk requirement (2 litres),

Net surplus milk quantity $=28$ litres per day

Value of milk on monthly basis@Rs.40 per litre $=28 \times 30 \times 40=$ Rs. 33600 per month

Cost of rearing HF breed ( 7 cattle) :
Capital cost $=7 \times 40000=$ Rs. 280000

Recurring cost per month (Concentrate + Medicine + Misc. $)=$ Rs. 5000

Considering 6 months of milking per annum,

$\begin{aligned} & \begin{array}{l}\text { Repayment } \\ \text { vestment }\end{array} \\ & \text { ual Returns }\end{aligned}=\frac{280000+(5000 \times 12)}{33600 \times 6}=1.68$ years

\section{Farm pond}

In order to meet the peak water requirement during summer season (in absence of nearby stream, canal or reservoir), it is essential to have a farm pond with sufficient storage capacity to harvest and store the rain water during monsoon. The required storage capacity of a farm pond could be calculated with known parameters such as, average annual rainfall, mid-size open well daily yield, seasonal crop water requirement, evaporation losses etc. The average annual rainfall of Kerala is $2817 \mathrm{~mm}$ against the mean annual rainfall of $1200 \mathrm{~mm}$ all over India (Krishnakumar et al., 2009)

The seasonal water requirement of summer crops i.e. maize and green gram is $2500 \mathrm{~m}^{3} \mathrm{ha}^{-}$ 1 and $2400 \mathrm{~m}^{3} \mathrm{ha}^{-1}$ respectively. This water demand could be partially fulfilled by considering average seasonal yield of an open well about $2400 \mathrm{~m}^{3}$ (5 to $15 \mathrm{~m}^{3}$ day $^{-1}$ ). Therefore the actual rainwater harvesting capacity should be $2500 \mathrm{~m}^{3}$. However, we also need to take account of evaporation losses, which is normally taken as the 20 to 40 per cent of the required storage capacity. Hence, assuming 30 per cent evaporation losses, the design storage capacity of the concerned farm pond comes around $3250 \mathrm{~m}^{3}$. To fit this required storage volume, we can design a square shape farm pond with trapezoidal cross section (side slope $=1: 1$ ) having $3.5 \mathrm{~m}$ depth, which results in the 24.8 $\mathrm{m}$ bottom width, $35.3 \mathrm{~m}$ top width and 1250 $\mathrm{m}^{2}$ surface area (Adhikari et al., 2008). 
The overall cost of such farm pond @ Rs. 125 $\mathrm{m}^{-3}$ excavation including the 300 micron plastic lining is around Rs. 406250. At present, financial assistance of 50 per cent of total cost limited to Rs. 75000 per unit for individual farmer is being provided under the scheme named National Mission on Sustainable Agriculture (NMSA) under Ministry of Agriculture and Farmers Welfare, Government of India (DAC\&FW, 2018b).

The irrigation water cost could assume to be 10 to 12 per cent of the gross value of agricultural produce. In the present case the indirect water cost yields a value of Rs. 20280 $\mathrm{ha}^{-1}$ per season. The comparison between cost of establishing farm pond with the irrigation water cost shows the payback period of 16 years. This payback period could be reduced significantly, if the farm pond is utilized for fresh water fish culture.

In conclusions, making a farmstead energy self-sufficient will not only increase our preparedness and chances of survival in time of crisis, but also will help us to reduce expenditure over the long-term by cutting down energy and water costs. In a critical situation, the ability to power a farmstead without reliance on a power grid, municipal water, or other external resource will greatly increase the chances of survival. Energy, heat, water and composting are the key elements in developing a truly self-sustaining farmstead. While planning for self-sustaining sources for energy, solar, wind energy and biomass conversion offer numerous renewable choices along with appropriate energy backup strategies.

RE technologies are essential for energy access, energy security, reduce dependency on fossil fuels, mitigating climate change (reducing emissions of greenhouse gases) and sustainability and socio-economic benefits (low-carbon economic growth and prosperity)
(IRENA, 2015). The possible economic, social and environmental benefits of renewable energy in rural areas are highlighted below:

REs are the clean and green sources of energy; have a much lower environmental impact than conventional energy.

Unlike, fossil fuels, RE is sustainable and will never run out.

RE would help reduce fossil fuel imports (saving foreign exchange)

RE such as solar, and wind energy can be used and extended in remote areas where it is too expensive to extend the electricity power grid.

$\mathrm{RE}$ projects in rural areas can bring social and economic benefits

Generating electricity from RE offers significant public health benefits to rural people (e.g. reducing premature child mortality and preventing exposure to harmful pollutants associated with use of fuel wood, cow dung, kerosene for cooking and lighting)

RE would facilitate educational and livelihoods activities in rural areas

RE technologies can help reduce environmental degradation such as desertification/deforestation, biodiversity depletion (by preventing use of forest woods for fuel)

RE would help recycle waste for energy (biogas) thereby, would reduce waste, cost of waste treatment, reduce environment risks, surface and groundwater pollution, odours, health and sanitary problems.

RE such as solar PV would be a viable option in supplying electricity for rural homes, rural markets, rural health clinics, rural street lighting, rural food production (irrigation pumping, agriculture, livestock, and aquaculture/fisheries production) and telecommunication. 
RE (biogas) can be used for household works, cooking, lighting etc.

Overall, RE would alleviate rural poverty, improve quality of life of rural women, men and children, reduce air pollution, create local employment, and enhance food production.

\section{References}

Adhikari, R., Mishra, P., and Muralidhar, W. 2008. Dugout farm pond -a potential source of water harvesting in deep black soils in deccan plateau region. In: Annual Meeting - Central Soil and Water Conservation Research and Training Institute (CRIDA), 26-28 June, 2008, Karnataka, pp. 29-35.

Ajaykumar, David, D. and Milford, H. 2009. Thermochemical Biomass Gasification: A Review of the Current Status of the Technology. Energies 2: 556-581.

Kissan Kerala, n.d. Crop information: Maize (Zea mays). Karshaka Information System, Services and Networking. Available:

http://www.kissankerala.net/kissan/kiss ancontents/maize.htm.

Dhia, A. 2015. Farmstead Planning (Farm Building design). Res. Gate [e-journal] $10 \mathrm{p}$.

Available: https://www.researchgate.net/publicatio n/272840813.

IRENA [ International Renewable Energy Agency], 2015. Renewable Energy Target Setting. IRENA home page. Available:

http://www.irena.org/DocumentDownlo ads/Publications/IRENA_RE_Target_S etting_2015.pdf.

Kibria, G. 2015. Sustainable Energy for Rural Development in Bangladesh- Economic, Social and Environmental Benefits of Renewable Energy. SydneybashiBangla [online].7p.Available: https://www.researchgate.net/publicatio
n/281378313_Sustainable_Energy_for_ Rural_Development_in_Bangladesh_Ec onomic_Social_and_Environmental_Be nefits_of_Renewable_Energy

Kibria G., Haroon A., and Nugegoda D. 2013. Climate change and agriculture, livestock, fisheries, and aquaculture food production. Am. J. Agric. Sci. Eng. Technol. 3(2): 300.

Krishnakumar, K., Rao, P. and Gopakumar, C. 2009. Rainfall trends in twentieth century over Kerala, India. Atmos. Environ. 43(11): 1940-1944.

Mahtta, R., Joshi, P. and Jindal, K. 2014. Solar power potential mapping in India using remote sensing inputs and environmental parameters. Renewable Energy 71: 55-262.

DAC\&FW [Department of Agricultural Cooperation and Farmers Welfare]. 2018(a). Minimum Support Price (MSP) and bonus for crop year 2017-18 [online].

Available: http://agricoop.nic.in/recentinitiatives/m inimum-support-prices-msp-and-bonuskharif-crops-2017-18-season.

DAC\&FW [Department of Agricultural Cooperation and Farmers Welfare]. 2018(b). Pattern of assistance in various schemes of DAC\&FW. Available: http://rkvy.nic.in/static/schemes/WaterH arvestingIrrigation.html.

OECD-IEA. 2006. Energy for cooking in developing countries. In: World Energy Outlook - The International Energy Agency (IEA) and the Organisation for Economic Co-operation and Development (OECD). 15: 419-445. Available:

https://www.iea.org/publications/freepu blications/publication/cooking.pdf

Rahman, M., Saha S., Khan, M., Habiba, U. and Sheikh, C. 2013. Present Situation of Renewable Energy in Bangladesh. Glob. J. Res. Eng. 13: 51-61. Available: https://globaljournals.org/GJRE_Volum 
e13/1

Renewable.pdf

TNAU Agritech. 2015. Cost of cultivation. Available: http://agritech.tnau.ac.in/agriculture/agri _costofcultivation_maize.html.
Wazed, M. and Islam, M. 2010. Prospect and future of biomass fuel: A review in Bangladesh perspective. Eng. e-Trans. 5(2): 61-66. Available: http://ejum.fsktm.um.edu.my

\section{How to cite this article:}

Khatawkar, D. S., P. S. James and Dhalin, D. 2020. Energy Self-sufficient Farmstead: Design Analysis. Int.J.Curr.Microbiol.App.Sci. 9(04): 3006-3025.

doi: https://doi.org/10.20546/ijcmas.2020.904.352 